\title{
Literatura y política: la función de la literatura en las primeras décadas del siglo $\mathrm{XIX}^{1}$
}

\author{
María José Rodríguez Sánchez de León \\ Universidad de Salamanca
}

\section{RESUMEN}

En este artículo se estudia la transformación experimentada por la función pública desempeñada por la literatura en las primeras décadas del siglo XIX como consecuencia de su dependencia respecto de las circunstancias históricas, políticas e ideológicas. A través del lenguaje y de la evolución de determinados conceptos estético-poéticos, se analiza cómo tras la Revolución Francesa se desarrolla una idea patriótica de la literatura, basada en el racionalismo y la moderación ilustrados, y su conversión en fanatismo político, resultado de la Guerra de la Independencia y del debate ideológico que culminó con la proclamación de la Constitución gaditana de 1812. El propósito es demostrar la utilización que los escritores y las instituciones realizaron de la literatura a lo largo de dicho periodo, los caracteres que la definieron y las conexiones que guardó con la constitución en España de una verdadera conciencia ciudadana.

Palabras Clave: literatura, función pública, Ilustración, Cortes de Cádiz, ciudadano, sensibilidad, entusiasmo, patriotismo, fanatismo, sátira.

\section{Literature and politics: The role of literature in the first decades of the $19^{\text {th }}$ Century}

\begin{abstract}
In this article we study the transformation in the public role played by literature in the first decades of the $19^{\text {th }}$ century as a consequence of its dependence on political, ideological and historical circumstances. Using language and the evolution of certain aesthetic-poetic concepts, we analyse how a patriotic idea of literature developed after the French Revolution, based on enlightened rationalism and moderation, and how it was converted into political fanaticism as a result of the Spanish War of Independence and the ideological debate that culminated in the proclamation of the Constitution of Cadiz in 1812. The aim is to show how writers and institutions made use of literature during this period, the characteristics that define this literature and how it was related to bringing about true citizen awareness in Spain.
\end{abstract}

Key words: Literature, Public role, Enlightenment, Cadiz Cortes, Citizen, Sensibility, Enthusiasm, Patriotism, Fanaticism, Satire.

${ }^{1}$ Este trabajo es resultado de los Proyectos de investigación La teoría europea de los conceptos estético-literarios en el siglo XVIII (18.KA4G), financiado por la Universidad de Salamanca, y del Proyecto I+D+i Historia de la literatura española entre 1808 y 1833 (FF12010-15098) del Ministerio de Ciencia e Innovación. 


\section{INTRODUCCIÓN}

El convulso periodo histórico comprendido por los años previos al Motín de Aranjuez y el regreso el 11 de mayo de 1814 de Fernando VII al trono de España constituye un lapso de tiempo en el que la literatura sufre similares transformaciones a las que experimenta la sociedad civil y la política nacional. Así, si bien tras la Revolución Francesa se insiste en proclamar que las bellas letras han de cumplir con la finalidad ético-política por la que abogara la Ilustración, entre los escritores e intelectuales europeos del periodo existía la conciencia de que debería hacerlo satisfaciendo los retos sociales y políticos de la nueva era. La literatura se valoró entonces como algo más que la expresión artística de la filosofía moral. Se convirtió en un medio excepcional para educar políticamente a la ciudadanía que había de constituir las sociedades modernas. De ahí que se pusiera al servicio de las capacidades intelectivas y sensitivas del ser humano y se utilizara para educar en aquellos sentimientos y afectos que se hallaban implicados en la organización políticamente legítima de los estados. Pero el devenir de los acontecimientos condicionará que se produzca una politización de la literatura que poco o nada tendrá ya que ver con los ideales ilustrados o con los afanes liberales. La poesía abandonará los ideales poéticos para expresar los sentimientos patrióticos. Me propongo, pues, analizar la evolución experimentada por la función pública que se atribuye a la literatura en dos momentos cruciales de la historia nacional: los años posteriores a la Revolución francesa y durante la Guerra de la Independencia y las Cortes de Cádiz. Para ello se estudiarán aquellos conceptos estético-literarios que definen en cada momento las relaciones de la literatura con la educación pública y la historia política. El objetivo es mostrar la evolución de los mismos y el determinismo ejercido en cada caso por la realidad circundante sobre el ser y el comportarse de la literatura.

\section{LOS INICIOS DEL SIGLO XIX: EL POETA COMO FILÓSOFO. LA UNIÓN ENTRE RAZÓN, SENSIBILIDAD, PROGRESO Y PERFECCIÓN COMO FUNDAMENTOS DEL PATRIOTISMO LITERARIO}

Al finalizar el siglo XVIII y comenzar el XIX, la literatura asumió que su función pública resultaba aún más relevante que la realizada en etapas anteriores. Cuando la Francia revolucionaria había acabado con la aprobación del despotismo como forma de gobierno, le correspondía educar en aquellos sentimientos y afectos propios de sociedades que se juzgan a sí mismas como libres. Su valor se cifra en que promueve, mediante la formación de ciertas capacidades vinculadas a la razón y a la sensibilidad (como es el caso del sentido común (Holt-Hoon, F. L. van y David R. Olson, 1987; Shaftesbury, 1995; Shaeffer, 1990 y Japaridze, 2000), de las emociones o de las pasiones), 
la formación de nuevos ciudadanos que, conscientes de sus responsabilidades y deberes, preservarán aquel orden público y aquellos gobiernos ilustrados que con su buen hacer demuestren proteger los derechos civiles.

No obstante, para que dicha función pública pudiera llevarse a término, las enseñanzas transmitidas por medio de la literatura debían de sustentarse en los principios fundamentales del racionalismo, esto es, sobre la base del convencimiento y la explicación frente a la imposición, además de expresarse con moderación. Por eso desde la prensa periódica, en los artículos de crítica literaria y en los tratados de poética del periodo de entre siglos se insiste en afirmar que la literatura, cuando demuestra de forma racional aquello que los hombres inteligentes perciben como verdadero, permite el progreso intelectual de los ciudadanos, el perfeccionamiento moral de las sociedades y, a consecuencia de ello, el mantenimiento del orden legítimamente establecido.

A este respecto, al principiar el siglo se insiste en manifestar la conexión existente entre los términos razón y progreso y de ambos con los conceptos de sensibilidad y perfección aplicados a la literatura y a los estudios literarios. Quien mejor sistematizó esta interrelación fue Mme. Stäel en su obra De la littérature considérée dans ses rapports avec les institutions sociales, publicada en 1800. El propósito declarado en la introducción es examinar cuál es la influencia de la religión, las costumbres y las leyes sobre la literatura, y lo contrario, a saber, cuál es el influjo ejercido por esta sobre la religión, las costumbres y las leyes (1800: I). Aunque la autora atiende a un concepto amplio de literatura, pues incluye las obras filosóficas y las obras de imaginación (1800: I), sin embargo analiza el efecto que la poesía en sentido lato ha de procurar sobre los lectores.

Desde su punto de vista, esta constituye un arte cuyo objetivo primero consiste en emocionar a los hombres. Pero de este propósito inicial, más sensible que placentero, ha de derivarse un objetivo intelectual que conduzca al ser humano a realizar acciones generosas: «Etudier l'art d'émouvoir les hommes, c'est approfondir les secrets de la vertu» (1800: VIII). La poesía debe, por tanto, inspirar no solo sentimientos de admiración procedentes de la contemplación de la belleza sino que también debe proporcionar un conocimiento intelectual de lo que es bueno (1800: pp. X-XI). Este planteamiento tan clásico y, al mismo tiempo, tan racionalista en su formulación supone una actualización sociopolítica del aristotelismo basada en la convicción de que, para avanzar social y moralmente, ha de educarse la razón y de que cuanto más avance esta mayor será el progreso de las naciones: «La connoissance de la moral a dû se perfectionner avec le progrès de la raison humaine» (1800: 172).

Establecer esta conexión entre conocimiento y moral suponía que la literatura en general no solo contribuía a mejorar intelectualmente al ser humano en tanto que individuo sino también como miembro de la res publica. El papel desempeñado por ella en las sociedades modernas resultaba determinante 
en la evolución de las sociedades porque enseñaba valores a los ciudadanos que la lógica y, por ende, su sentido de lo verdadero no podía cuestionar. Con este planteamiento, característico del optimismo ilustrado y de la estética racionalista, se pretendía distanciar los tiempos modernos de las antiguas civilizaciones y el despotismo del absolutismo. En 1801 se dice en el Memorial Literario refiriéndose a las diferencias entre ambas épocas: «Comparemos estos siglos con el presente y veamos cuál merece la preferencia por la dulzura y suavidad de costumbres, por la templanza de sus gobiernos, por la independencia de las naciones, y por la libertad, tranquilidad y conveniencia individual» (1801:18). El despotismo que desde los poderes públicos se ejerce en las últimas décadas del siglo XVIII y primeras del XIX insta a los ciudadanos a aceptar racionalmente que el gobierno actúa guiado por el bien común. No cuenta, al menos en apariencia, con la sumisión y el vasallaje como fundamentos de su estabilidad sino que asegura esta última en la demostración intelectual de lo que conviene al conjunto del Estado y de la sociedad.

Desde esta perspectiva, los progresos de la literatura resultan del máximo interés para el poder pues de ellos depende la supervivencia de los gobiernos e incluso, como señalara Mme. Stäel, la conservación de la libertad (1800: xxvii). En 1792 Leandro Fernández de Moratín, obviando, como es lógico, aludir a la libertad, constataba en La comedia nueva la existencia de tal relación cuando uno de sus personajes afirmaba: «Los progresos de la literatura, señor don Antonio, interesan mucho al poder, a la gloria y a la conservación de los imperios. El teatro influye inmediatamente en la cultura nacional; el nuestro está perdido y yo soy muy español» (1976: 117). Según de la cita se desprende, en la medida que la literatura se acomodaba a las circunstancias del presente, favorecía la estabilidad política de los estados. Pero «ser español» a comienzos del siglo XIX significaba para autores reformadores como Moratín hijo comprometerse con la realidad circundante, reflejarla, representarla y juzgarla. Por eso sus comedias critican comportamientos y tipos socialmente negativos: El viejo y la niña, El Barón y La mojigata, sin ir más lejos. La experiencia estética constituye de este modo una experiencia de la demostración de tal manera que permite la independencia racional del sujeto y su acceso al mundo de las luces. Moratín en su «Advertencia» a El sí de las niñas aseguraba haber tenido que vencer la oposición de quienes se oponían al «progreso rápido de las luces y esta oposición poderosa han tenido que temer los que han dedicado en ella su aplicación y su talento a la indagación de verdades útiles y al fomento y esplendor de la literatura y las artes» (1976: 162). El poeta construye así un universo de la lógica sobre el que puede y debe levantarse la vida en común. A este respecto, conviene señalar que los dramaturgos recurren a las leyes del arte para justificar que la comedia no hace sino representar «costumbres nacionales» y una «moral practicable». De ahí que la literatura y, en particular, el género cómico, se destinara a mostrar costumbres contemporáneas que, siéndonos propias, sirvieran para adoptar 
comportamientos característicos del hombre de bien en la vida cotidiana o para rectificar aquellos otros que se consideraban perniciosos. En 1803 el periódico madrileño El Regañón General definía así las costumbres:

[...] Pudiera decir[se], hablando en general, que son hábitos buenos o malos que resultan del temperamento, de los usos, de las opiniones, y que forman el carácter de los hombres y de los pueblos. Los que han definido las costumbres dicen que son la práctica de las acciones honestas, el cumplimiento de las obligaciones que nos impone la sociedad, la virtud puesta en acción, y la inclinación a desempeñar nuestros deberes comprobada por la observación continua, y por la conducta diaria del hombre de bien (1803: 473).

De este modo, lo que se plantea es que la sociedad contemporánea debe regirse por un concepto moderno o, quizá sea más adecuado decir, modernizado de la virtud y que el conocimiento de esta última mejora al progresar la razón humana. Tras la Revolución, lo que podemos denominar la pedagogía democrática se constituye en Francia, Alemania y, por analogía, en España, salvando por supuesto las distancias ideológicas, sobre la base de la moral y de una idea renovada de la virtud. Diderot, Chénier, Goethe y la misma Stäel invocan a la virtud, en sentido utilitario o idealista, como fundamento de la política y de las instituciones. La moral se constituye en elemento articulador de las sociedades cuando los ciudadanos asumen sus deberes respecto del Estado. De nuevo en palabras de Mme. Stäel:

La connoissance de la moral a dû se perfectionner avec le progrès de la raison humaine. C'est à la morale sur-tout que, dans ordre intellectuel, la démonstration philosophique est applicable. Il ne faut paut comparer les vertus des modernes avec celles des anciens comme hommes publics; ce n'est que dans les pays libres qu'il existe de généreux rapports et de constants devoir entre les citoyens et la patrie (1800: 172) $)^{2}$.

Es evidente que España no podía considerarse una nación propiamente libre. Pero tampoco era ya una sociedad sometida a la doctrina del Antiguo Régimen. Años atrás ya lo había recogido el Espíritu de los mejores diarios al afirmar:

En un gobierno equívoco o tumultuario, en el reinado de un tirano, son temibles las costumbres porque como dicen relación a todo, a todo pueden conducir y un déspota ha de temer mucho el tener vasallos cuya energía pueda excitarse por una conciencia sana e irreprensible. Pero en un país en el que la filosofía ha hecho

${ }^{2}$ Según la autora, no habían sido suficientemente estudiadas las causas morales y políticas que modificaban el espíritu de la literatura, argumento que sostiene su libro y que, aunque remite a Montesquieu y a Marmontel, no había sido desarrollado con anterioridad. En el caso español, debe tenerse en cuenta que dicha interrelación se convierte en una constante entre los teóricos e historiadores de la literatura durante el Trienio Liberal cuando la literatura se estima como un instrumento individual de control social. Véase lo comentado en Rodríguez Sánchez de León, 1999: 55-68 y 2004: 47-52. 
grandes progresos, en que las luces se propagan, en el reinado de un príncipe sabio, bueno y virtuoso, las costumbres se han de apreciar, merecen toda consideración y se han de restaurar en su verdadero estado. Pues, siendo el teatro [...] el lugar en que puede aprenderse el gusto, me parece esencial el que se le obligue a que siga las reglas de la razón y de la moral (1789: 139-140)³.

Por eso la literatura, el teatro, habían de asumir nuevos compromisos institucionales, compromisos que, en líneas generales, se basaban en la difusión de los principios del buen gusto y en la transmisión de buenas costumbres: «L'esprit républicaine — dirá Mme. Stäel— exige plus de sévérité sans le bon goût, qui est inséparable des bonnes moeurs» (1800: 70).

Esta conexión política de las costumbres con las nociones de buen gusto y moralidad que establece la escritora francesa se convertirá en una constante de la literatura europea de comienzos del siglo XIX. El gusto constituye, como explica Munárriz al traducir a Blair, «una especie de poder compuesto en el cual la luz de la razón más o menos se mezcla siempre con los impulsos del sentimiento» (1816 [1798], 39-40 y Rodríguez Sánchez de León, 2010: 37-56). Y esa vinculación con la inteligencia permite su corrección: «La corrección del gusto — se dice en el Blair español— se refiere principalmente a la mejora que recibe esta facultad por su conexión con el entendimiento» (1816: 30). Por eso, aunque se admite la desigualdad entre los hombres en materia de gusto, se asegura que es la facultad más perfectible de cuantas posee el ser humano (Blair, 1816: 23 y 24).

En efecto, siendo una facultad en origen natural, el gusto mejora a medida que se educa y cultiva y la educación no es sino el resultado de un conocimiento o, si se prefiere, del convencimiento de la razón (Blair, 1816: 23). De ahí que la extensión de las luces implique la mejora intelectual del gusto el cual a su vez asumirá las ventajas de la moral y el orden garantizando, en definitiva, la supervivencia de los estados (Batteux, 1797: 105-108). Un gusto correctamente educado permite, también en palabras de Munárriz: «alimentar en nuestras almas el patriotismo, el amor de la gloria, el desprecio de la fortuna externa y la admiración de las acciones verdaderamente grandes e ilustres» (1816: 15-16 y también Batteux, 1797: 105). En consecuencia, los poseedores de gusto no podrán sino defender valores morales (Batteux, 1797: 80). De este planteamiento se infieren tres conclusiones: la primera, que las sociedades avanzan a medida que los hombres de luces instauran el buen gusto en el común de las gentes; la segunda, que cuanto más libres sean las sociedades mayor extensión y refinamiento ha de exigirse del gusto y, la tercera, que su divulgación constituye una tarea que han de desarrollar ciudadanos excepcionales cuya idea del gusto y de la moral les permite dirigir intelectualmente a sus compatriotas.

\footnotetext{
${ }^{3}$ Explicaciones muy parecidas fueron utilizadas por los teóricos europeos y españoles para el diferenciar el teatro antiguo del moderno. Véase a modo de ejemplo el discurso de Pedro Estala en el que la sensibilidad constituye un concepto diferenciador de la actitud del espectador ante las representaciones trágicas y, en definitiva, de las civilizaciones (1793: 20-21).
} 
Comenzando por esta última cuestión, el literato de entre siglos ha de comportarse ante sus semejantes como un auténtico filósofo. $\mathrm{Si}$, como asegura el Memorial Literario en 1801, «la verdadera filosofía consiste en el uso conveniente y adecuado del juicio y de la razón» (1801: 36), por filósofo se entiende el hombre de luces que utiliza una forma lógica y rigurosa de pensar en beneficio de la humanidad (Álvarez de Miranda, 1992: 454-461) ${ }^{4}$. De hecho, así lo proclaman dos artículos publicados en 1804 en El Regañón General. En ellos se manifiesta que la filosofía es «una ciencia práctica» que «procura la felicidad de los hombres» (1804: 255). En este contexto, el poeta se erige en «maestro de los otros hombres» (Lista: 1821,465$)^{5}$ ya que reconoce ser amigo del progreso, detractor del escolasticismo y defensor de la moral católica y de la monarquía. Esto significa que su saber le permite indagar en el conocimiento de la realidad, analizarla y proponer, cuando proceda, su reforma. Como escribió Maravall: «con lo que el siglo XVIII llama filosofía el ilustrado quiere desentrañar el mundo para reformar la sociedad» (1976: 155)6. Mas su anhelo de lograr la felicidad común le impedirá defender novedades subversivas. Por el contrario, los cambios que institucionalmente se aprueban habrán de referirse al progreso científico y a la prosperidad económica, social y moral de los estados que hace mejorar la monarquía. La idea de revolución que entonces se proclama ha de entenderse como evolución histórica. En palabras de nuevo de Moratín: «Una extraordinaria revolución va a mejorar la existencia de la monarquía, estableciéndola sobre los sólidos cimientos de la razón, la justicia y el poder» (1868: III, 200 y 210). La revolución tal y como Moratín la entiende supone casi lo contrario de lo que el vocablo designa. La racionalidad que el poeta imprime a su ideología le permite alentar cambios que serán percibidos como positivos pero nunca como desestabilizadores del estado. El literato-filósofo por el que claman los ilustrados del XVIII y del XIX es, como en 1820 lo definió Alberto Lista, un «hombre virtuoso, amigo de la humanidad y bienhechor de sus semejantes» (1821: 228). En otras palabras, es un ser legitimado por su sabiduría y bondad para conducir a la nación por esos mismos derroteros ${ }^{7}$. Manuel José Quintana, en la dedicatoria

\footnotetext{
${ }^{4}$ Conviene recordar que Juan Andrés en su obra Origen, progresos y estado actual de toda la literatura. aboga por el recto pensar de origen cartesiano como fundamento del correcto razonar frente a lo que considera la invasión del llamado «estilo espiritoso» (1997: II, 368-397). Véase, a este respecto, Garrido Palazón (1995: 75-96); Rodríguez Sánchez de León (1996: II, 1136-1147) y Checa Beltrán (1997: 423-435).

${ }^{5}$ Lista establece una conexión entre el escritor público que se guía de un espíritu filosófico con una actitud humanista, esto es, con la voluntad de servir al género humano para mejorarle intelectual y moralmente.

${ }^{6}$ Alberto Lista define la filosofía como «la investigación o indagación de las causas y de la esencia de las cosas en cualquier línea que sea» (1820: 228-229).

${ }^{7}$ El poeta-filósofo cumplía con sus obligaciones al promulgar a través de sus escritos virtudes morales generales como se desprende de las siguientes palabras de Mariano Luis de Urquijo: «Nadie puede reputarse por un verdadero poeta dramático sin ser un filósofo
} 
de sus Poesías (1813) a su amigo Cienfuegos, señala: «De ti aprendí a no hacer de la literatura un instrumento de presión y de servidumbre, a no envilecer jamás ni con la adulación ni con la sátira la noble profesión de escribir, a manejar y respetar la poesía como un don que el cielo dispensa a los hombres para que se perfeccionen y se amen, y no para que se destrocen y corrompan» (1969: 335 y Lama, 2009: 19-33).

Sin embargo, el escritor-filósofo de comienzos de siglo adoptó en ocasiones un patriotismo más exaltado. En 1805 Sánchez Barbero, glosando poéticamente a Marmontel pero mostrando su conciencia liberal, afirmaba: «Para nosotros la utilidad política de la tragedia no se diferencia de la utilidad moral. La felicidad y la gloria del gobierno monárquico dependen de las buenas costumbres del soberano» (1834: 248). A medida que nos acerquemos al año 1808, los autores se implicaron más en los acontecimientos políticos, politizándose también el discurso literario. La poesía patriótica y la tragedia son los géneros que mejor lo reflejan. En ellos se observa cómo el poeta, bajo la fórmula de lo simbólico, arremete contra el tirano y el fanatismo. Quintana, por ejemplo, exhibe su patriotismo a través de personajes heroicos, como Guzmán el Bueno, Juan de Padilla o Pelayo, o sucesos memorables como el combate de Trafalgar, que representan el símbolo de la rebelión española. La historia nacional adquiere una dimensión ideológica en el contexto de los errores cometidos por Carlos IV y su ministro Godoy pues, como apunta el Memorial Literario, «la Historia es el cuadro moral donde están pintadas las acciones de los hombres. Observándolas con espíritu analítico se llega a conocer su bien o su mal. De esto se deduce la buena elección y de aquí la mejor aplicación que podamos hacer de nuestra conducta moral y política» (1805: 118). La reconstrucción literaria del pasado nacional posee una intención ejemplarizante porque a través de ella se puede anatematizar la tiranía, el fanatismo y la represión. La correspondencia con viejas situaciones enseña a reconocer las equivocaciones y a reaccionar frente a otras nuevas políticamente equivalentes. En el mismo periódico se dice que se ha de recurrir a la Historia: «para saber las causas que los indujeron a los errores o a los aciertos, para examinarlas si acaso nos hallásemos en las mismas circunstancias y admirar sus virtudes, talentos y saber para imitarlos y aun para ansiar noblemente superarlos» (1805: 119). Ante el presentimiento de la lucha antinapoleónica, la literatura opone la tiranía a la libertad de los pueblos e incluso fundamenta sobre la primera el ocaso de la monarquía:

\footnotetext{
Muerto el tirano veis: ya no hay reposo;

siglos y siglos duren las contiendas;

y si un pueblo insolente allá, algún día,

al carro de su triunfo atar intenta

la nación que hoy libramos, nuestros nietos
}

porque sus obras son el fruto de la verdadera filosofía. El poeta dramático ridiculiza el vicio y aplaude la virtud siempre con agrado» (1791: 63). 
su independencia así fuertes defiendan, y la alta gloria y libertad de España con vuestro heroico ejemplo eternas sean (Jornada V, acto V, 1822: 56).

El cuestionamiento por parte de los ilustrados afrancesados, y sobre todo de los liberales, de la licitud del absolutismo, se reflejó en una manifiesta intolerancia hacia cualquier forma de gobierno en la que los súbditos no asumieran de forma racional la existencia de un pacto contractual entre los soberanos y el pueblo. De hecho, como algunos autores reconocieron después, la estimación pública de algunas obras que así lo defendían se debió a la intención política que albergaban. Quintana recuerda así el éxito de su Pelayo:

Todo lo cubrió [...] — dice refiriéndose a los defectos poéticos de su composición-, el interés patriótico del asunto: los sentimientos libres e independientes que animan la pieza desde el principio hasta el fin, y su aplicación directa a la opresión y degradación que entonces humillaban nuestra patria, ganaron el ánimo de los espectadores, que vieron allí reflejada la indignación comprimida en su pecho, y simpatizaron en sus aplausos con la intención política del poeta (1821 y Romero Ferrer, 2009: 293-317).

Como Quintana explica en 1821, en los umbrales de la Guerra de la Independencia la literatura representó alegóricamente la realidad contemporánea. Bajo la apariencia de enunciados políticos universales, se expone la idea de que la nación española no puede permanecer impasible ante el opresor. Por eso, aunque los escritores aparenten comportarse como el moderado sentir ilustrado aconsejaba, esto es, demostrando que los ciudadanos, convertidos en tales por obra de la educación, del racionalismo filosófico y del ascenso social de las clases medias, no podían sino repudiar la tiranía, al mismo tiempo exigían con sus versos la resolución de la situación catastrófica que vivía España proponiendo, más o menos subrepticiamente, un inconformismo popular.

Hay que recordar, sin embargo, que la férrea censura ejercida entre 1800 y 1808 limitaba al poeta hasta el punto de que su ideología política se expresa casi siempre en clave universal. La defensa de la libertad de Quintana en su oda A la invención de la imprenta se plantea en términos de un universal humanismo difícil de contradecir:

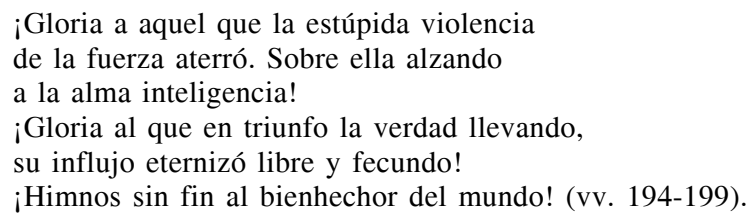

Algo más vehemente se muestra, sin embargo, en la versión segunda y definitiva del poema, también del año 1800. En este caso, la invención de la imprenta y la libertad del hombre se unen para reivindicar planteamientos que permiten una lectura política. El poeta elogia a Guttemberg para afirmar «El 
hombre es libre» (v. 158). Pero se trata de una libertad intelectual, cultural, en la línea de lo expresado por Mme. Stäel, no exactamente política. Esta intencionalidad se oculta bajo la idea de que los individuos intelectualmente libres rechazan la esclavitud que el tirano persigue y pierden el miedo al opresor:

Los hombres todos su igualdad sintieron,

y a recobrarla las valientes manos

al fin con fuerza indómita movieron.

No hay ya, ¡qué gloria!, esclavos ni tiranos (vv. 188-191).

El lenguaje empleado expresa por ello el odio al tirano y al opresor de los pueblos. Transmite una idea del funcionamiento político del Estado opuesta a la que defendiera el despotismo. Lejos estamos de versos como los que en 1788 escribía García Malo en Doña María de Pacheco, mujer de Padilla: «¿Qué divina ni humana ley permite / que el vasallo por fines indiscretos / alborotos levante y haga guerra / a un señor natural que le da el Cielo?» (1996: $105)^{8}$. Esta proclama absolutista contrasta con la concepción de las relaciones entre la monarquía y la sociedad civil procedente de Montesquieu y De l'Esprit de lois a la que nos venimos refiriendo (Iglesias, 1984: 312-319 y Koebner, 1951: 275-302). Un gobierno de aquella naturaleza no es sino un gobierno arbitrario carente de eficacia y de legitimidad política; es inestable y débil. Por ello recurre al terror y a la sumisión. De ahí que convenga creer en una monarquía moderada en la que la felicidad pública se alcanzara a través del logro de la «mayoría de edad» como diría Kant, de la sociedad civil.

Mas lo que durante las últimas décadas del siglo XVIII suponía la inexistencia del pensamiento único bajo la fórmula de la moderación y el comedimiento, con la invasión francesa y la celebración de las Cortes de Cádiz, se torna en la expresión vehemente de las opiniones. La literatura que antes había servido para mantener la estabilidad de la monarquía, se convierte en expresión más política que poética de las ideologías en pugna.

\section{LA GUERRA DE LA INDEPENDENCIA Y DE LAS CORTES DE CÁDIZ: LA CON- TRIBUCIÓN DEL POETA A LA CAUSA PÚBLICA Y EL DESENVOLVIMIENTO DEL ESPÍRITU PATRIÓTICO}

Mor de Fuentes, al prologar su comedia El egoísta o El mal patriota de 1812, escribe: «[se] me ocurrió el retratar un egoísta que, concentrado todo

\footnotetext{
${ }^{8}$ No obstante, hay que recordar que en 1811 García Malo se manifiesta contrario al despotismo, entendiendo por tal la opresión y tiranía del gobierno. Sobre el mensaje ideológico de la tragedia, véase, además de la introducción de Carnero, Andioc (1999: 71-84) y Sala Valldaura (2005: 361-367). En relación con su liberalismo, compruébese cómo su Política natural, publicada por vez primera en 1811, es concebida para «ilustrar al pueblo sobre sus derechos y deberes y darles ideas de la verdadera política» (1820: iv y vi respectivamente).
} 
en la pequeñez de su empedernida mezquindad, se niega a contribuir por su parte a la causa pública, prescindiendo de la sinrazón y las resultas de tan pernicioso sistema» (1990: 51 y Gil Novales, 1995: 7-18). A partir de 1808, cuando el pueblo español se levanta en defensa de su legítimo rey Fernando VII, los literatos ponen sus escritos a disposición de eso que Mor llama la causa pública y que consistía en la salvaguarda a ultranza del monarca, de la patria y de los derechos del pueblo español frente a la dominación extranjera.

La gravedad de los acontecimientos determina la reacción literaria de los escritores que, conscientes de su responsabilidad política y civil en tan crítica situación, se despreocupan de ser fieles a la referencialidad mimética predicada por el clasicismo para instaurar una literatura al servicio de la defensa patriótica del pueblo español. No es, pues, exagerado afirmar, como reconociera Antonio Alcalá Galiano, que la política invadió la literatura: «La política, y exclusivamente la política del momento, se convirtió no solo en el tema de toda clase de escritos, sino hasta de toda clase de pensamientos» (1969: 36). Al igual que sucede con la prensa periódica, que da cumplida cuenta de cuanto diariamente sucede interpretando los acontecimientos según la ideología de los periodistas, la literatura procura no permanecer indiferente ante las circunstancias. Los poetas saben que ha llegado la hora de demostrar algo más que su patriotismo convirtiéndose en portavoces de los sentimientos de la sociedad española en su conjunto. Quintana lo explica así en la «Advertencia de las poesías patrióticas de 1808»:

Inspirados estos versos por el amor a la gloria y a la libertad de la patria, manifiestan ya la indignación de que un pueblo fuerte y generoso sufriese el yugo más infame que hubo nunca, ya la esperanza de sacudirle y de que tomásemos en el orden político y civil el lugar que por nuestro carácter y circunstancias locales nos ha asignado la naturaleza, ya, en fin, la desesperación de ver desvanecerse con el aspecto que tomaban las cosas públicas esta hermosa y grande perspectiva (1969 $332)^{9}$.

La literatura, por consiguiente, deja de comprenderse como representación poética de la realidad para convertirse en expresión patriótica de las diferentes corrientes de opinión de los autores y de la reacción condenatoria del pueblo español. La literatura, como diría Blanco White respecto de los periódicos, «se miró bajo un aspecto más importante» (Durán López, 2003: 585).

${ }^{9}$ Esa conciencia del deber del hombre de letras ante las circunstancias la expresa asimismo en la Memoria del Cádiz de las Cortes: «Nadie ignora cuánto obra la opinión en las crisis políticas y cuánto influyen en ellas los hombres de letras. El retiro, el silencio les es imposible entonces y, agitados del celo, de la ambición y de la presunción también, ellos son los que generalmente en estos casos abren la senda o la allanan a los estadistas y a los militares» (1996: 78). Sobre el «patriotismo» de los escritores, véase Álvarez Barrientos (2006: 101-108) y Sánchez García (2008: 159-190). 


\subsection{El entusiasmo poético: del patriotismo al fanatismo}

Esta importancia histórica que debemos atribuirle radica en que los escritores desean convertir la literatura en un instrumento más de la lucha contra los franceses, equiparable en su vehemencia y en su fuerza persuasiva a la que los ciudadanos estaban librando en el campo de batalla. El poeta, por tanto, además de no permanecer impasible, se sentía obligado a alentar a sus compatriotas a reaccionar ante la ignominia que estaba sufriendo la población. Capmany lo expresaba claramente en su Centinela contra franceses del año 1808:

No es este tiempo de estarse con los brazos cruzados el que puede empuñar la lanza ni con la lengua pegada al paladar el que puede usar del don de la palabra para instruir y alentar a sus compatriotas. Nuestra preciosísima libertad está amenazada, la patria corre peligro y pide defensores: desde hoy todos somos soldados, los unos con la espada, los otros con la pluma (1808: 2).

El teatro y la poesía patrióticos se dirigen a enardecer al público y a provocar la ira contra el tirano. De ahí que esta clase de literatura busque hacerse persuasiva por medio de una enunciación apasionada y de un lenguaje directo: «iGuerra, guerra, españoles!» (v. 105) grita Quintana en uno de sus versos de su composición «A España, después de la revolución de marzo» de 1808.

La literatura se convierte entonces en el lenguaje de las pasiones pero de las pasiones políticas generadas por la principal de todas, esto es, por el patriotismo. De hecho, como bien se explica en la definición que proporciona El Semanario patriótico en 1808, este constituye una virtud pública más instintiva que racional: «Sentimiento exaltado y sublime producido por el instinto más bien que por la reflexión, amigo y compañero de la bondad de costumbres y de las virtudes; sentimiento que se alimenta de sacrificios, que prefiere en todos tiempos y en todas ocasiones el interés público al individual, fuente eterna de heroísmo y de prodigios políticos y el resorte más poderoso para elevar y conservar los Estados» (1808: 48). El patriotismo se convierte de esta forma en un estado de ánimo latente en la sociedad que resurge cuando esta se siente amenazada: «No aparece — se dice en el mismo artículo- sino cuando las adversidades públicas le despiertan y las agitaciones políticas le devuelven su energía» (1808: 49). De él dimanan sentimientos de exaltación y entusiasmo tales como el odio, la indignación, el orgullo que, precisamente por su condición de arrebatos violentos, permiten la reacción de la sociedad contra el tirano y opresor. De nuevo leemos en el Semanario: «Este tiempo vino ahora para nosotros y los días de marzo le empezaron. El español que desde aquellos días se contemplaba con patria, viendo que se la intentaban arrancar, corrió indignado a las armas y con los pedazos de las cadenas que acababa de romper humilló la arrogancia de los tiranos. Los prodigios de valor y de osadía se suceden rápidamente unos a otros en nuestras provincias y se 
repiten por todas partes aquellos hechos que la antigüedad nos presenta como efusiones de la exaltación y entusiasmo más patrióticos» (1808: 50).

Para la preceptiva neoclásica el entusiasmo consistía en una especie de furor poético que poseían algunos seres privilegiados (Batteux: 1753, 185$187)^{10}$. Afectaba principalmente al genio inventivo y a los sentimientos del poeta el cual no debía convertir la obra artística en su expresión ya que supondría abandonarse a sus propias emociones. El entusiasmo debía, por el contrario, mantenerse en los límites de lo prescrito de forma que lo emotivosentimental se somete al componente de ficción racional que toda obra literaria constituye (Saura Sánchez: 1992, 111-129). Pero lo cierto es que junto a este mesurado empleo del entusiasmo, al «entusiasmo noble» como lo denominó Shaftesbury en 1708, de origen leibniziano, que se hallaba muy próximo a la virtud y a lo sublime (1997: 137-139 y Wolf, 1988: 46-53), existía otro tipo de entusiasmo, el entusiasmo de la exaltación, no regulado por la norma. Este último constituía un enardecimiento provocado por emociones tremendas cuya principal característica consistiría en el gran poder de contagio social que se le atribuye. Su naturaleza se entiende que es profundamente humana lo cual provoca que, como fuerza afectiva, cause en los demás similar apasionamiento. El autor de Quejas de rey don Fernando VII desde su prisión a sus leales vasallos declara en el prólogo de su obra pretender con ella que «se dirija a ejercitar los ánimos españoles para que (despreciando riesgos) alivien el tierno llanto de tan amado dueño» (1808: 3 y Larraz, 1988 y Freire López, 1995, 872-896; 2005, 1-26 y Palacios y Romero Ferrer, 2004: 185-242; Romero Peña, 2007).

La literatura patriótica responde a esta segunda categoría del entusiasmo. Domina en ella lo emocional y el poeta, como representante y voz del pueblo español, convierte su creación en expresión espontánea de los sentimientos arrebatados generados por el objeto, en este caso, por los agravios cometidos por las tropas francesas (Shaftesbury, 1997: 104-105). Uno de los personajes de la pieza en un acto de Enciso Castrillón titulada El sermón sin fruto dice refiriéndose al efecto que infundirá el discurso de Pepe Botella: «Con esta arenga yo aguardo / que el populacho se inflame, / y se llene de antusiasmo» (Larraz, 1987: 32). La poesía y el drama patrióticos son el resultado artístico del ardor político de los autores que al comienzo de la contienda reaccionan con viveza pasional para animar al pueblo español a oponerse al despotismo. Unos versos de la composición de Quintana titulada «A España, después de la revolución de marzo», compuestos en abril de 1808 lo testimonian:

${ }^{10}$ En cambio, Blair, que sigue a La Motte y su Discours sur l'ode (1707), alude a él con un tono crítico pues por él se justifican el desorden de estas composiciones líricas (1816: 387-389). 


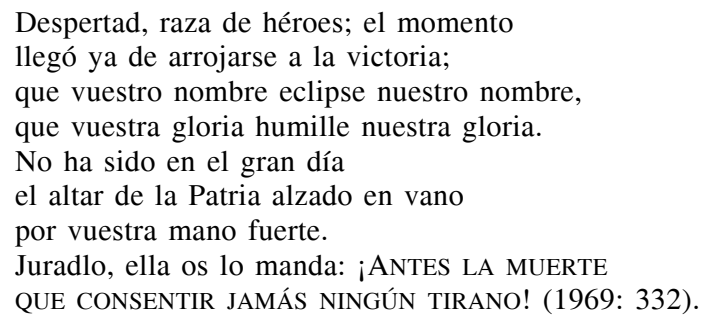

De hecho, algunos años después, en concreto en 1812, en La Abeja española se asegura que la supervivencia de las letras españolas depende del entusiasmo y este se relaciona con la excitación que provocan los sucesos históricos memorables y los héroes que los protagonizan: «Aun viven las musas españolas porque viven la virtud y el valor, la sensibilidad y el entusiasmo. La edad del heroísmo fue y será siempre la de la noble poesía pues los grandes ejemplos excitan irresistiblemente ideas y expresiones grandiosas» (1812: 14-15). Según de aquí se infiere, el entusiasmo, cuando se le otorga un carácter general, está muy próximo al concepto de inspiración, alienta a los grandes hombres, sean estos escritores, políticos o filósofos (Shaftesbury, 1997: 138) siendo, en consecuencia, necesario para que estos puedan llevar a cabo actos grandiosos. Poemas como el citado y otros muchos alusivos a otros acontecimientos como, por ejemplo, los dedicados por Martínez de la Rosa a la rendición de la ciudad de Zaragoza poseen esta cualidad ${ }^{11}$.

No obstante, como también explicara Shaftesbury, mientras este entusiasmo es positivo para la humanidad, un entusiasmo desmesurado conduce a sentimientos falsos pudiéndose confundir con el fanatismo. La propia Madame Stäel en su libro sobre Alemania (1810) lo había así expresado (1991: 188). Böhl de Faber, siguiendo a la autora francesa, repite en 1818 en lo que estriba la diferencia: «Muchos malquieren el entusiasmo porque lo confunden con el fanatismo y en esto se engañan. El fanatismo es una pasión exclusiva cifrada en alguna opinión; el entusiasmo abraza el universo. En él se confunde la admiración de lo sublime, el amor hacia lo bello y el dulce abandono de la propia personalidad. El sentido de esta palabra en griego es 'Dios en nosotros'» (1818: 71). Aunque el fervor de converso de Nicolás Böhl de Faber le inclina a otorgarle un origen no ya divino sino católico al entusiasmo, demostrando con sus opiniones su propio fanatismo religioso (Shaftesbury, 1997: 129-136), lo cierto es que en los escritos de los primeros años de la contienda resulta fácil encontrar manifestaciones de un apasionamiento patriótico excesivo. Ciertos escritores, sobre todo aquellos que se reconocen profanos en

\footnotetext{
${ }^{11}$ Véanse como ejemplo los primeros versos: «Sobre ruinas y triunfos Zaragoza / de la terrible lucha reposaba / que por dos lunas agitó su suelo / cuando, a la voz de Marte pavorosa, / se estremeció Pirene, y de sus cumbres, / con las armas y el hierro amenazando, / lanzárose mil bárbaras legiones», Martínez de la Rosa, 1836: 199.
} 
la profesión, llenan sus composiciones de imágenes exageradas que demuestran no solo el desprecio sino el odio que sienten hacia los franceses. En cambio, una vez que se aprueba la Constitución esta clase de arrebatamiento, convertido no pocas veces en fanatismo, convivirá con la voluntad de otros hombres de letras de manifestar su alegría por la instauración de las libertades y con el afán de ilustrar a los lectores en el conocimiento de sus derechos y deberes civiles, si bien generalmente lo hacen para avalar sus propias convicciones políticas.

\subsection{Literatura patriótica, literatura política y tipología discursiva}

Efectivamente, un primer momento de apasionamiento patriótico se observa en las obras teatrales que se publicaron o representaron antes de la celebración de las Cortes de Cádiz. Muchas de ellas son piezas breves, escenas unipersonales o obras en un acto de pronta recepción en las que se insta a la población a cumplir con su deber patriótico. Mas entre ellas podemos diferenciar las que utilizan un tono mesurado de aquellas otras en la que se injuria al enemigo. Corresponden a la primera categoría de discursos las obras protagonizadas por Fernando VII, que son ante todo quejas y lamentos, y las piezas alegóricas donde el pueblo y la nación española son tratados magnánimamente por el poeta que les atribuye toda clase de virtudes relacionadas con el honor, el patriotismo, la lealtad y el valor.

Los suspiros, ayes y penas de Fernando VII se utilizan para mover el corazón de sus súbditos. Su patriotismo se asienta sobre la base de la apelación a la sensibilidad y solidaridad del público al conocer los padecimientos de su rey. La literatura no hace sino provocar la identificación entre el monarca y sus vasallos los cuales, al «escuchar» lamentarse de su suerte al rey, se compadecen de su sufrimiento. De este modo, la figura del monarca se humaniza para favorecer que la población reaccione en defensa de la patria. En la obra de 1808 titulada Quejas del rey don Fernando clama este: «Rescatadme, vasallos, atendiendo / que como rey os llamo a la defensa, / y como amigo amado, os lo ruego» (1808: 8). Los ciudadanos sienten como un igual a su rey de forma que sus peticiones se perciben como justas. En $L a$ voz de Fernando VII que clama desde su prisión por el auxilio de las armas de sus fieles vasallos, escrita por Fernández de Agüero en el mismo año que la anterior, cuyo título resulta suficientemente revelador de lo que estamos afirmando, leemos:

Oíd, Españoles, fieles, generosos, oíd los tristes clamores y gemidos que desde su prisión el gran Fernando transmite gemebundo a vuestros oídos. Oíd de un rey virtuoso e inocente 
de un rey injustamente perseguido

los suspiros que exprime y justas quejas

contra un tirano cruel y fementido.

$[\ldots]$

Añadiendo poco después:

El dios de las batallas os inspire

sentimientos de amor y patriotismo;

y aunque sé los tenéis, aun más deseo

que se aumente en vosotros el heroísmo (s.a.: 3).

En cierto modo, un comportamiento literario similar se encuentra en las obras alegóricas. En ellas se representan personajes simbólicos para distribuir virtudes y defectos entre los bandos enfrentados. La universalidad inherente a la alegoría implica una nacionalización histórica de las cualidades eternas del carácter español. Supone, por tanto, la transformación de un fenómeno en concepto con la intención de realizar la instrucción no ya moral sino político-patriótica del lector. Zavala y Zamora construye en La sombra de Pelayo o El día feliz de España (1808) un discurso apologético en el que el héroe nacional se enfrenta al Despotismo. Junto a Pelayo están España, la Lealtad y el Valor mientras que acompañan al Despotismo la Ambición, la Codicia, el Orgullo, la Lascivia, el Egoísmo, la Adulación, la Crueldad y la Intriga francesa. Ni que decir tiene que el lamento del protagonista y de España está plagado de interrogaciones retóricas en las que apela a la recuperación de la dignidad española recordando sus triunfos más memorables. Se habla de la necesidad de defender la «dulce independencia» nacional del despotismo «tirano», «fiero» y «terrible» (Larraz, 1987: 58, 59 y 70 y Carnero, 1991). La literatura representa maniqueamente dos mundos enfrentados, el de la virtud y el orden legítimo, y el del mal, el caos y la crueldad. Ambos se corresponden con una dicotomía léxica dependiendo de que se haga referencia al opresor o se aluda al oprimido. Como es lógico, se caracteriza despectivamente al invasor y positivamente al pueblo humillado y a Fernando VII. Pero en este tipo de obras, como en las antes mencionadas, existe cierta contención en el lenguaje que desaparece en otras obras de naturaleza burlesca o jocosa.

La clara intención propagandística que preside estas últimas así como el carácter liberador inherente a la sátira convierten estas obras en un ataque expreso a Napoleón y a su hermano y, por extensión, a los intrusos. No es de extrañar que en ellas los apelativos que reciben los franceses sean los peores posibles aunque el grado de insulto varía en función de las limitaciones que el poeta se impone. En El sermón sin fruto de Félix Enciso Castrillón se les llama «malditos gabachos» (acto I, esc. 1) (Larraz, 1987: 16). Incluso al finalizar la pieza todos los personajes que representan al pueblo español, zapatero, panadero, sastre, vendedoras de frutas... gritan al unísono: «¡Mueran todos 
estos perros!» (Larraz, 1987: 42), repitiéndose tan funesto deseo en obras que hacen referencia la triunfo final como en La gran victoria de España de Valladares del año 1813 donde el gracioso e ignorante Langosta dice: «Que mueran los chanfutres» (Larraz, 1987: 122).

Mas ninguna barrera existe en la lírica y el teatro cuando se describe satíricamente a Napoleón, a su hermano o a Godoy, al que se culpa de la situación española. La literatura no es ya un instrumento de propaganda política sino un vehículo de militancia contra las figuras que encarnan el odio de los españoles. En la titulada Tragicomedia infernal en un acto: Napoleón y sus satélites residenciados por el Rey del abismo de 1809 se dice respecto de Godoy: «Tú todo lo mereces, vil culebra / seductor de mujeres, traidor fiero (J.O.Y, 1809: 13 y Romero Peña, 2007: 117). Los dramas protagonizados por Napoleón, como estudió en su día David Gies, caracterizan al Emperador siguiendo criterios propios del «frenesí antinapoleónico» que arraigó en la opinión popular (1991:46 y Marco, 1977: II, 518-524 y Díaz, 2008: 223-238). En La muerte de Bonaparte, también de 1808, el autor le califica de «usurpador vil», «asesino», «ladrón detestable», «sangriento», «embustero», «tirano horrendo» (Gies, 1991: 48) y en otro texto titulado El engaño francés se le describe del siguiente modo:

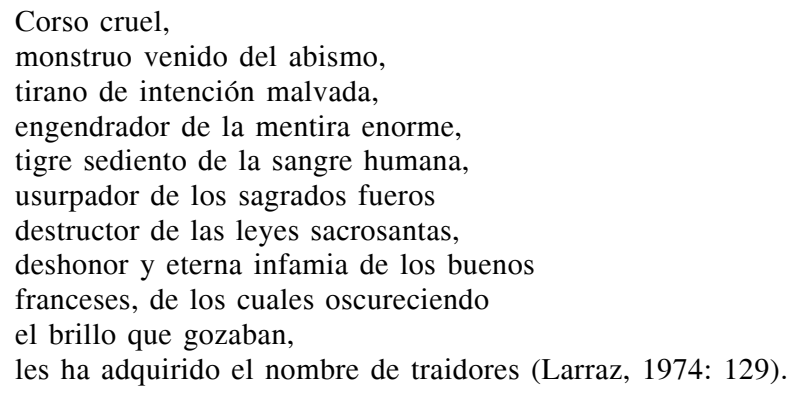

La crudeza de las descalificaciones constata no ya la intención del autor sino las impresiones que los hechos y los personajes de la guerra causaron en el hombre común. Por eso la sátira no siempre se mantiene en los límites de lo ingenioso. A menudo se produce un ataque sin humor que la convierte en pura reprobación. En esas ocasiones, manifiesta un odio social que limita su trascendencia histórica. A este respecto, son perfectamente pertinentes las palabras de Blanco White a propósito de la sátira y del compromiso del escritor: «El poeta satírico debería ser siempre un moralista profundo a fin de evitar que lo tomen por un mero envidioso y resentido. Pero en el presente estado de la sociedad civilizada nadie puede ser un buen moralista ni, empleando otro términos, un buen moralista, ora enseñe desde el púlpito o despacho, ora se sirva del verso o la prosa para comunicar sus lecciones, puede dejar de causar daño a menos que realice un largo y paciente estudio de la socie- 
dad a la que pertenece» (1974: 324). Carente, por consiguiente, del efecto cómico y del propósito intelectual o moral que debería animarla, la mala sátira se focaliza en el insulto para convertirse en invectiva (Frye, 1957: 297). El lenguaje insultante y desmesurado de este tipo de obras posee un efecto catártico para un pueblo ofendido que encuentra consuelo en la satanización literaria del enemigo.

Mas la literatura de la Guerra de la Independencia no utilizó solo procedimientos verbales propios del libelo infamatorio. También hubo literatos que adoptaron una actitud más propiamente ilustrada componiendo textos que les ennoblecieran como autores y como patriotas y que el público, superada la visceralidad de los primeros años, supo apreciar ${ }^{12}$. La literatura popular convivió con otras composiciones más canónicas cuya intencionalidad resultaba propiamente política. Incluso podría afirmarse que tras la aprobación de la Constitución, hubo un nutrido número de escritores y periodistas que devolvieron a la literatura el carácter pedagógico que antaño tuvo. A su entender, la nación necesitaba disponer de una literatura instructiva puesta al servicio de la libertad y de los españoles. Estos precisaban de una formación que, de un lado, les permitiera conocer los derechos y deberes que la Constitución gaditana les otorgaba y, de otro, les enseñara a desenmascarar a tipos sociales que impedían el progreso político de la nación.

Pertenecen a este grupo la comedia de Martínez de la Rosa Lo que puede un empleo y la tragedia La viuda de Padilla, ambas de 1812, y El egoísta o El mal patriota de Mor de Fuentes, escrita el mismo año, así como algunas piezas traducidas ${ }^{13}$. Martínez de la Rosa, que transmitió en su comedia las máximas de la doctrina liberal que él profesaba, justifica la publicación de Lo que puede un empleo diciendo:

El vivo deseo de presentar en el teatro a cierta clase de hipócritas políticos que so color de religión se oponen entre nosotros a las benéficas reformas, me esti-

${ }^{12}$ En 1812 el Diario de Madrid publicó una queja firmada por un «buen español» en donde se contaba lo siguiente: «Es el caso que desde que salí de casa hasta llegar a la Puerta del Sol no dejé de oír gritos de ciegos publicando Napoleón rabiando y otras producciones de este jaez, y por casi todas las librerías de la calle de las Carretas y por las esquinas de la plazuela del Ángel y Puerta del Sol vi que volvían a presentarse aquellos mamarrachos indecentes que ofenden menos a los que satirizan que a sus autores y a los que los buscan y que se repetían los anuncios de varios folletos despreciables, que degradan el carácter de la nación, dando la idea menos ventajosa de su decoro e ilustración y que solo pueden servir de asunto de risa a los hombres que no piensan, y de mofa y desprecio aun a los mismo franceses 'Señor Diarista'», Diario de Madrid, 1812, n. ${ }^{\circ} 236$ (13 sept.), pp. 361-362.

${ }^{13}$ Blanco White contra la mala interpretación de patriotismo: «Cuando una inclinación natural es elevada a la categoría de virtud, sobrevienen los males mayores. El patriotismo es un ejemplo de ello. La propensión natural a conferir una importancia indebida a nosotros mismos se denomina egoísmo cuando el individuo es claramente el objeto de su propio sentimiento. Pero cuando, bajo el nombre de patriotismo, cada individuo se deja arrastrar a la vanidad, al orgullo, a la ambición, a la crueldad $-\mathrm{y}$ lo hace en calidad de inglés, francés o español一, todos estos vicios son considerados virtudes» (1974: 304). 
muló a emprender [...] la composición de esta comedia. [...] Pero habiendo merecido en el teatro unos aplausos [...] y habiendo hecho reír a costa de los que, por ignorancia o por malicia, intentan desacreditar las nuevas instituciones me he decidido a imprimirla, deseando contribuir de todos modos a que el público conozca a los enemigos de nuestra libertad (1963: 9).

La obra resulta igualmente moderada desde el punto de vista del lenguaje. El autor rehúsa motejar a los españoles serviles limitándose a defender los valores del liberalismo que opone a la simpleza, el egoísmo y maledicencia de Don Melitón y a la ignorancia del padre de la joven. En la escena primera Doña Carlota le repite a su amante los dicterios con los que su padre se refiere a él, liberal convencido: "'sus ideas — dice emulándole — son las peores del mundo; el trato con esos locos de liberales le ha quitado el juicio y se ha vuelto un revolucionario..., un jacobino...' ¿Qué sé yo?... Así... dijo una porción de nombres, todos malos... todos malos...» (1836: 406-407). Más tarde se le llama «revoltoso afilosofado». Sin embargo, en la comedia se aclara que estos juicios no se fundan en verdad objetiva alguna, sino en temores irracionales que proceden del desconocimiento y de la calumnia (1836: 409). Por eso el poeta selecciona de entre los despectivos calificativos que se les atribuyeron los adjetivos que poseen un referente político relacionado con las ideas que desde el siglo XVIII sostenían los reformadores, esto es, revolucionario, jacobino y afilosofado (Seoane, 1968: 157). La obra pretende con ello proporcionar argumentos de índole ideológica a la causa que el poeta defiende. De ahí que el lenguaje del personaje que abraza la causa liberal contraste argumentalmente con el de los antiliberales. Su discurso constituye una exposición razonada de sus planteamientos. Aun cuando trata de defenderse de falsas acusaciones promovidas por los serviles, su parlamento constituye un ejemplo de inteligencia, conocimiento y mesura. Don Teodoro se queja ante su padre de no ser escuchado replicándole: «Es imposible, imposible: no escucha la razón. El temor de faltar a la religión lo hace sordo a todas las reconvenciones; en vano tratará usted de persuadirle» (Martínez de la Rosa, 1836: 436). Ambos personajes intentan demostrar con su actitud la falsedad de las acusaciones de sus adversarios políticos y cómo estos las perpetúan para favorecer sus intereses personales ${ }^{14}$. La obra responde así a los conceptos de liberal y servil que en 1814 recoge el Diario Mercantil de Cádiz:

El liberal es, como parece indica su nombre, el amigo de que el ciudadano goce de aquella justa libertad que solo le sujeta a la razón o, lo que es lo mismo, a la

${ }^{14}$ Véase a este respecto la crítica contenida en la Abeja española de 1812: «Quiso ridiculizar en ella a los hipócritas políticos, es decir, a cierta gavilla de bribones que de todo maldice, aun cuando sea muy bueno y muy santo, si por casualidad no ven en ello su conveniencia, pues como la vean, bien puede caerse el cielo sobre los demás que seguro está que ellos despeguen sus labios. El resultado de aquellas composición fue colmar el público de aplausos a su autor y reírse a costa de los hipócritas políticos», p. 120. 
ley que es hija de esta [...]. El servil es, como indica su nombre, un amigo de la esclavitud, así como el liberal es defensor de la libertad según la hemos pintado sujeta a la ley (1814: 14; Seoane, 1968: 160).

Al igual que se recoge en el Semanario Patriótico de 1811, la literatura opone la sensatez de los reformadores a la incultura y el deseo de reinstaurar el despotismo de los serviles: «Los serviles [...] — se dice en este periódicoson muy dados a la traición, [...] la calumnia es su arma favorita. Con ella acometen a los honrados patriotas llamándolos públicamente herejes y ateos para que el incauto pueblo los deteste y persiga, si bien este conoce ya quien es su verdadero enemigo y quien el defensor de sus derechos. [...] Finalmente estos caníbales llevan en su negro estandarte la siguiente divisa: persecución y despotismo» (1811: 127-128).

Es cierto que se vertieron similares graves acusaciones por parte de los adeptos a uno u otro bando político. Tantas que los propios literatos comprendieron que había llegado el momento de abandonar los partidismos que inducían al fanatismo. Cierta literatura recupera así la vocación docente que años ha tuviera. Al menos en apariencia, recuperaba su estatus poético y con él su voluntad de ofrecer un servicio público.

\title{
3.3. Contra el fanatismo: la llamada a la neutralidad en la literatura. La educación del buen ciudadano y la recuperación de la verdad
}

En la Abeja española de 1812 se lee: «Desengañémonos, mientras no se olviden los nombres de liberal y antiliberal y mientras no se prescinda del carácter y circunstancia de los sujetos que opinan sobre los asuntos públicos, nada adelantaremos. La verdad no necesita de la recomendación que pueda darle el sujeto que la defiende, ella por sí sola basta para obrar eficazmente en el corazón del hombre honrado y sin prevención» (1812: 30-31). Después de 1811, y probablemente debido a que en las sesiones de Cortes se trató este asunto, la literatura y la prensa empiezan a manifestarse contrarias a perpetuar una lucha que juzgan estéril. Francisco de Paula Martí en La Constitución vindicada (1813) lo expone en los siguientes versos:

\author{
Estos partidos opuestos, \\ esta guerra de opiniones \\ es solamente un efecto \\ de la novedad; no todos \\ ven de un mismo modo: aquello \\ que para unos es claro \\ es para otros un completo \\ laberinto. La razón \\ es la que al fin en un gremio \\ reunirá los contrarios.
}




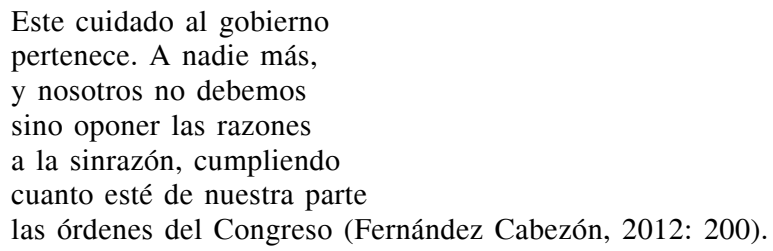

Parece que resulta más provechoso dedicarse a una causa patriótica más elevada. Esta consiste en alabar la Constitución y, en virtud de ella, enseñar a los ciudadanos a comportarse como tales y a demandar sus derechos. Un poema de Francisco Sánchez Barbero muestra ya desde el título esta renovada presencia de lo patriótico: Oda al Patriotismo. A la nueva Constitución (1814): «Cómo a ser ciudadano / y a conocer enseña / tu excelsa dignidad y poderío!».

Durante la primera etapa del conflicto, esto es, antes de la celebración de las Cortes de Cádiz se hablaba de «buenos ciudadanos» y «españoles verdaderos» para referirse colectivamente al pueblo español que defendía el trono y el altar del acoso de las tropas invasoras ${ }^{15}$. En cambio, en tiempos de las Cortes se recurre a la condición de ciudadano para expresar, como bien recoge la Abeja española, un «carácter político [...] que antes no teníamos» (1812: 114). Es interesante que en 1808 los «malos ciudadanos» son los «bellacos» que aceptan como rey a José $\mathrm{I}^{16}$. Por el contrario, en 1812 el mal ciudadano es, según lo define el periódico citado, «el holgazán, el hipócrita, el egoísta, el estafador, el embaucador, el intrigante, el avaro, el poltrón y los que profesan otros vicios», los tipos sociales que la comedia retrata (1812: $116 \mathrm{y} \mathrm{n})$, aquellos que se aprovechan de la libertad que la Constitución les confiere en beneficio propio.

La literatura se dedica a esclarecer nuevos conceptos políticos para los que el pueblo llano no estaba preparado. En la pieza en un acto de Zavala y Zamora La palabra Constitución, cuya primera redacción data de 1813, el rudo alcalde un pueblo ignora el significado explicado finalmente por el médico. Dice el primero:

[...] Eso será aquello que dicen que mandaron las Cortes hace años, ¿no es verdad? [...]. Como después la quitaron [...] ¿Es cierto o no es cierto que el rey la mandó quemar y que no se volviese a hablar de semejante cosa? [...] Porque si es así yo no entro en tales celebraciones, porque ya ve usted que no será muy buena cuando S. M., que es tan bendito, no quiso nada con ella; con que si entonces era mala, también será mala ahora... (Fernández Cabezón, 2012: 213).

La Constitución se define en la obra en términos jurídicos como el orden fundamental de la nación en el que se declara que la soberanía pertenece al

${ }^{15}$ Es el caso de las composiciones de Félix Enciso Castrillón, El sermón sin fruto (Larraz, 1987: 24) y A. B. Núñez, Calzones en Alcolea (Larraz, 1987: 190).

${ }^{16}$ Así también en Félix Enciso Castrillón, Ibídem (Larraz, 1987: 24). 
pueblo y en donde el rey representa el papel de un buen padre. En La Constitución vindicada de Francisco de Paula Martí un alcalde, algo más ilustrado que el anterior, declara:

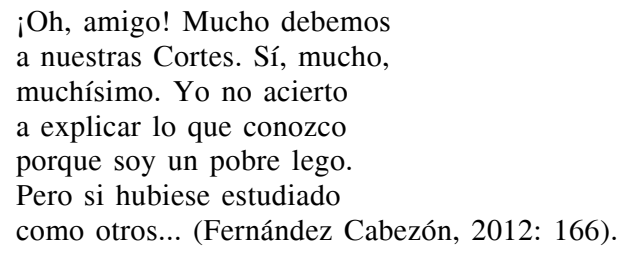

La obra expone sin ambigüedades lingüísticas los cambios sociales que un mentecato servil de nombre Don Ruperto reprueba:

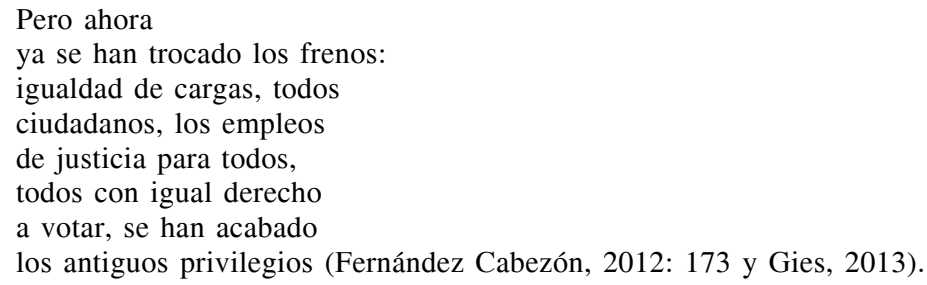

Ciudadanía, libertad e igualdad se ponen en correlación. «No es ciudadano - se apostilla en una nota de la Abeja española- el que habita la ciudad sino el que entra en parte al goce de la soberanía» (1812: 114). Como en este mismo periódico se declara, la literatura en cualquiera de sus ramos debía contribuir a demostrar la conveniencia individual derivada de la instauración de un régimen constitucional. El interés público consistía entonces en que el hombre común supiera si sus principios y valores le convertían en un ser constitucional o anticonstitucional conociendo cuáles eran las ventajas de los dos regímenes políticos.

En este sentido, la literatura reivindica la ciudadanía como un derecho que, lejos de causar la desestabilización de los gobiernos, se convierte en garante de los mismos mediante el pacto de respeto mutuo realizado por el monarca y los súbditos (que no vasallos). Tómese como ejemplo el poema «Venid, ciudadanos»:

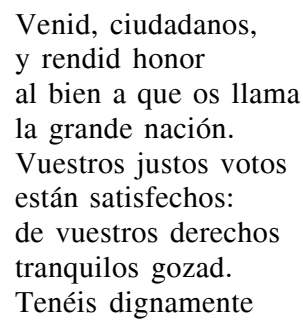


por dicha colmada
el ver sancionada
vuestra libertad $^{17}$.

Esta literatura más que patriótica resulta política al constituir una actualización de la comedia de costumbres o de la tragedia histórica. De igual modo, a la poesía se le atribuye un propósito docente en virtud del cual se enseña al hombre común, que se había convertido en ciudadano por obra y gracia de la Constitución, lo que esta nueva condición supone. Resultan oportunos aquí los versos de Cienfuegos en su tragedia Pítaco, obra de tinte revolucionario compuesta a finales del siglo XVIII e impresa en 1816:

Lecciones necesitan los mortales

mucho mas que rigor; porque sus yerros

de ceguedad o de ignorancia nacen.

Dictarles su deber con el ejemplo,

hacer que vean la virtud, que la amen,

y solo por su amor obren lo recto:

con estas leyes se gobierna al hombre.

Ignorantes, feroces, eso han hecho

las armas del terror por donde quiera:

las virtudes pacíficas nacieron

por siempre del amor y la dulzura (Johnson, 1972: 569 y Glendinning, 1984).

\section{CONCLUSIÓN}

A lo largo de las primeras décadas del siglo XIX el proceso de transformación política que tuvo lugar en la sociedad europea determinó que la literatura utilizara los ideales de progreso y ciudadanía de la Ilustración para inculcar valores propios de lo que entonces se entendía por civilidad y modernidad. Pero, en el caso español, la invasión napoleónica acabó con la moderación ideológica y poética por la que abogara el siglo XVIII. Los escritores asumieron un papel en la vida pública más comprometido políticamente y la literatura, el lenguaje literario y los discursos dejaron de representar las pasiones morales para mostrar las pasiones políticas incluido el fanatismo que trajo consigo la Guerra de la Independencia. Fue entonces cuando se inició un camino de no retorno en el que el pueblo, la soberanía y la patria se convirtieron en vocablos cargados de nuevos significados. Cuando, como afirmara

${ }^{17}$ Tras el estribillo continúa del siguiente modo: «[...] Leyes constituyen, / leyes que, cual muros, / nos dejan seguros / de injusto agresor. / Y acordes sancionan / que den aun los reyes / a tan santas leyes / respeto y honor. / Venid, ciudadanos... / Su voz inmutable / la nación levanta: / el poder quebranta / de Napoleón. / Y es de sus esfuerzos / fruto soberano, / callar el tirano, / si habló la nación. / Venid, ciudadanos...», Abeja Española, 1813: 35-36 (Bravo Liñán, 2005: 390-391). 
Lista en 1820, el pueblo se definió como la universalidad de los ciudadanos (1820: 259), la soberanía como «el poder superior a todos los demás poderes de la sociedad» (1820: 263), y la patria, la unidad superior que reúne a los ciudadanos bajo la garantía de las leyes (1821: 97), la literatura no hizo sino demostrar, parafraseando a Erhard, que «un pueblo ilustrado exige ser tratado según la dignidad de la humanidad» (1989: 99).

\section{BIBLIOGRAFÍA CITADA}

La Abeja española, 1812. N. ${ }^{\circ} 83$ (4 oct.), pp. 30-31.

Alcalá Galiano, Antonio (1969). Literatura española del siglo XIX. De Moratín a Rivas. Trad. y ed. V. Llorens. Madrid: Alianza Editorial.

Álvarez Barrientos, Joaquín (2006). Los hombres de letras en la España del siglo XVIII. Apóstoles y arribistas. Madrid: Castalia.

Álvarez de Miranda, Pedro (1992). Palabras e ideas: el léxico de la Ilustración temprana en España (1680-1760). Madrid: RAE.

Andioc, René (1999). «Doña María Pacheco, ¿mensaje preliberal?», en Guillermo Carnero, Ignacio Javier López y Enrique Rubio (eds.), Ideas en sus paisajes. Homenaje al profesor Russell P. Sebold. Alicante: Universidad.

Andrés, Juan (1997-2001). Origen, progresos y estado actual de toda la literatura, ed. Verbum / Biblioteca Valenciana.

Batteux, Charles (1753). Principes de la littérature. Paris: Desaint y Saillant.

Batteux, Charles (1797-1801). Principios filosóficos de la literatura traducida al castellano por José Luis Munárriz. Madrid: Sancha.

Blair, Hugo (1816-1817). Lecciones sobre la Retórica y las Bellas Letras, las tradujo del inglés D. José Luis Munárriz. Madrid: J. Ibarra.

Blanco White, José María (1974). Obra inglesa. Barcelona: Seix Barral.

Blanco White, José María (2003 [1811]). «Tercera época del Semanario patriótico», El Español. II (1811), n. ${ }^{\circ} 10$ (30 en.), en Fernando Durán López (ed.). Crónicas de Cortes del Semanario Patriótico, 1810-1812. Cádiz: Fundación Municipal de Cultura/Ayuntamiento de Cádiz.

Böhl de Faber, Nicolás ([1818]). Tercera parte del Pasatiempo crítico en defensa de Calderón y del antiguo teatro español. Cádiz: Carreño.

Bravo Liñán, Francisco (ed.) (2005). La poesía en la prensa del Cádiz de las Cortes, 18101813. Cádiz: Ayuntamiento de Cádiz.

Capmany, Antonio de (1808). Centinela contra franceses. Madrid: Gómez Fuentenebro y cía.

Checa Beltrán, José (1997). «Juan Andrés y el 'estilo espiritoso'», Revista de Literatura, LIX, 118 , pp. 423-435.

Carnero, Guillermo (1991). «Temas políticos contemporáneos en el teatro de Gaspar Zavala y Zamora», en Ermanno Caldera (ed.). Teatro politico spagnolo del primo Ottocento, ed. E. Caldera. Roma: Bulzoni, pp. 19-41.

D.D.M.S. (1808). Quejas del rey don Fernando VII desde su prisión a sus leales vasallos. Madrid: Impr. de Josef Doblado.

Díaz, Joaquín (2008). «De una tradición subterránea: 1808 en la cultura popular entre siglos», en Joaquín Álvarez Barrientos (ed.). La Guerra de la Independencia en la cultura española. Madrid: Siglo XXI, pp. 223-238.

Erhard, J. B. (1989). «Sobre el derecho de un pueblo a una revolución (1795)». En Aa. Vv. ¿Qué es Ilustración?. Madrid: Tecnos. 
«Es preciso tomar un partido», La Abeja Española, 1812. N. ${ }^{\circ}$ 15, 26 de sept., pp. 113-118.

Estala, Pedro (1793). Edipo tirano, tragedia de Sófocles, traducida del griego en verso castellano, con un discurso preliminar sobre la tragedia antigua y moderna. Madrid: Sancha.

Fernández de Moratín, Leandro (1868). Obras póstumas. Madrid: Rivadeneyra.

Fernández de Moratín, Leandro (1976). La comedia nueva y El sí de las niñas, ed. de J. Dowling y R. Andioc. Madrid: Castalia.

Fernández de Agüero, Juan Manuel (s.a.). La voz de Fernando VII que clama desde su prisión por el auxilio de las armas de sus fieles vasallos, [s.i.t.].

Fernández Cabezón, Rosalía, ed. (2012). La Constitución de Cádiz en el Teatro Español, de la época de las Cortes al Trienio Liberal (1812-1822). Cádiz: Biblioteca de las Cortes de Cádiz.

Freire López, Ana Mª (1995). «Teatro político durante la Guerra de la Independencia», en Víctor García de la Concha (dir.). Historia de la literatura española. Siglo XVIII. Madrid, Espasa-Calpe. II, pp. 872-896.

Freire Lopez, Ana Ma . (2005). «La literatura española en 1808», Revista de Historia Militar. 2, pp. 1-26.

Frye, Northon (1957). Anatomía de la crítica. Caracas: Monte Ávila, 1957.

García Malo, Ignacio (1820). La Política natural o Discurso sobre los verdaderos principios del gobierno. Barcelona: José Lluch.

García Malo, Ignacio (1996). Doña María Pacheco, mujer de Padilla, ed. de Guillermo Carnero. Madrid: Cátedra.

Garrido Palazón, Manuel (1995). Historia literaria, Enciclopedia y ciencia en el literato jesuita Juan Andrés. Alicante: Instituto de Cultura Juan Gil Albert/Diputación provincial.

Gies, David (1991). «Hacia un mito anti-napoleónico en el teatro español de los primeros años del siglo XIX», en Ermanno Caldera (ed.), Teatro politico spagnolo del primo Ottocento, Roma: Bulzoni, pp. 43-62.

Gies, David (2013). «La Pepa se va al teatro», en Durán López et alii, Actas del V Congreso Internacional de la Sociedad Española de Estudios del siglo XVIII. En prensa.

Gil Novales, Ramón (1995). «El Patriota de José Mor de Fuentes: primera etapa (1812)». Spagna Contemporanea. 8, pp. 7-18.

Glendinning, Nigel (1984). «Morality and Politics in the Plays of Cienfuegos», Modern Language Studies. 14, 2, pp. 69-83.

«Guerra político-literaria entre liberales y serviles, y preliminares de paz que propone un aventurero», Semanario Patriótico, 1811. N. ${ }^{\circ}$ LXXIV (29 ag.), pp. 127-128.

Holt-Hoon, F. L. van y David R. Olson (1987). Common sense: the foundations for social science. Boston: University Press of America.

«Idea del siglo XVIII», Memorial Literario, Época $2^{\mathrm{a}}$. I , 1801. N. ${ }^{\circ}$ 1, pp. 14-34.

Iglesias, Carmen (1984). El pensamiento de Montesquieu. Madrid: Alianza Editorial.

J.O.Y. Tragicomedia infernal en un acto: Napoleón y sus satélites residenciados por el Rey del abismo (1809). Málaga: Carreras e Hijos.

Japaridze, Tamar (2000). The Kantian Suject: Sensus Communis, Mimesis, Work of Mourning. Albany: State University of New York Press.

Johnson, Jerry L. (ed.) (1972). Teatro español del siglo XVIII. Antología. Barcelona: Bruguera.

Koebner, R. (1951). «Despot and Despotism: Vicissitudes of a Political Term», Journal of the Warburg and Courtauld Institutes. 14, 3-4, pp. 275-302.

Lama, Miguel Ángel (2009). «La poesía selecta de Manuel José Quintana», en Fernando Durán López, Alberto Romero Ferrer y Marieta Cantos Casenave, La patria poética. Estudios sobre literatura y política en la obra de Manuel José Quintana. Madrid: Iberomericana, pp. 19-33. 
Larraz, Emmanuel (1974). «La satire de Napoleón Bonaparte et de Joseph I dans le thêâtre espagnol: 1808-1814», en Hommage à A. Joucla-Ruau. Aix-en-Provence: Université de Provence, pp. 125-137.

Larraz, Emmanuel (1997). La guerre d'Independance espagnole au théâtre: 1808-1814. Anthologie. Aix-en-Provence: Université de Provence.

Larraz, Emmanuel (1988). Théatre et politique pendant la Guerre d'Independance espagnole: 1808-1814. Aix-en-Provence: Université de Provence.

Lista y Aragón, Alberto (1820) «De la autoridad del pueblo en el sistema constitucional», El Censor. II, p. 259.

Lista y Aragón, Alberto (1820). «Discurso sobre la filosofía de las artes y ciencias en general y de la literatura en particular», El Censor. T. VI, n. ${ }^{\circ} .21,23$ dic., pp. 223- 235 y (1821), t. IV, n. ${ }^{\circ} 24,13$ en., pp. 454-466.

Lista y Aragón, Alberto. «De los odios nacionales y políticos», El Censor, 1821. XII, n. ${ }^{\circ}$ 68 (17 nov.), pp. 81-107.

«Literatura», La Abeja Española, 1812, 13 sep., pp. 14-16.

Maravall, José Antonio (1976). «El primer siglo XVIII y la obra de Feijoo», en II Simposio sobre el padre Feijoo y su siglo. Oviedo: Universidad de Oviedo, pp. 151-195.

Marco, Joaquín (1977). Literatura popular en España en los siglos XVIII y XIX. Madrid: Taurus.

Martínez de la Rosa, Francisco (1836). Poesías y dos comedias. Los celos infundados y Lo que puede un empleo. Madrid: Salvá e Hijos.

Martínez de la Rosa, Francisco (1963). Obras. Madrid: Atlas, BAE, 148.

Mor de Fuentes, José (1990). El egoísta y La fonda de París, ed. Fernando Doménech y Juan Antonio Hormigón. Madrid: ADE.

Palacios Fernández, Emilio y Romero Ferrer, Alberto (2004). «Teatro y política (1789-1833): entre la Revolución Francesa y el silencio», en Joaquín Álvarez Barrientos, (ed.). Se hicieron literatos para ser políticos. Cultura y política en la España de Carlos IV y Fernando VII. Madrid: Biblioteca Nueva, pp. 185-242.

«Política. Reflexiones sobre el patriotismo», Semanario patriótico, 1808. ․‥ 3 (15 sep.), pp. 47-51.

«¿Qué se debe entender por costumbres?», El Regañón General, 1803. N.. 60, 24 dic., pp. 470-473.

Quintana, Manuel José (1822). Pelayo, tragedia en cinco actos. Valencia: Mompié.

Quintana, Manuel José (1969). Poesías completas, ed. Albert Derozier, Madrid: Castalia.

Quintana, Manuel José (1996). Memoria del Cádiz de las Cortes, ed. Fernando Durán. Cádiz: Universidad de Cádiz.

«Reflexiones sobre el estudio de la Historia», Memorial Literario, 1805. T. II., n. ${ }^{\circ} .12$ (30 abr.), pp. 118-127.

«Reflexiones sobre el teatro de M. Charnois», Espíritu de los mejores diarios, 1789. ․․ 184 (8 jun.), pp. 139-140.

Rodríguez Sánchez de León, María José (1996). «La filosofía y el conocimiento teórico de la literatura a fines del siglo XVIII», en Aa.Vv. El mundo hispánico en el Siglo de las Luces. Actas del Coloquio Internacional Unidad y diversidad en el mundo hispánico en el siglo XVIII. Madrid: Sociedad Española de Estudios del Siglo XVIII/ Fundación Duques de Soria/ Universidad Complutense. II, pp. 1136-1147.

Rodríguez Sánchez de León, María José (1999). La crítica dramática en España (1789-1833). Madrid: CSIC.

Rodríguez Sánchez de León, María José (2004). «Prensa periódica y crítica literaria», en Álvarez Barrientos, Joaquín (ed.). Se hicieron literatos para ser políticos. Cultura y política en la España de Carlos IV y Fernando VII. Madrid: Biblioteca Nueva, pp. 25-62. 
Rodríguez Sánchez de León, María José (2010). «La teoría del gusto y el canon del realismo burgués en el siglo XVIII», Res pública. Revista de Filosofía política, 13, 23, pp. $37-56$

Romero Ferrer, Alberto. «'El teatro suele ser un instrumento muy poderoso en manos de la política': Quintana en el teatro», en Fernando Durán López, Alberto Romero Ferrer y Marieta Cantos Casenave. La patria poética. Estudios sobre literatura y política en la obra de Manuel José Quintana, Madrid: Iberoamericana, pp. 293-317.

Romero Peña, M ${ }^{a}$ Mercedes (2007). El teatro de la Guerra de la Independencia. Madrid: FUE.

Seoane, María Cruz (1968). El primer lenguaje constitucional español: las Cortes de Cádiz. Madrid: Moneda y Crédito.

Shaftesbury, Conde de (1997). Carta sobre el entusiasmo. Barcelona: Crítica.

Sala Valldaura, Josep María (2005). De amor y política: la tragedia neoclásica española. Madrid: CSIC.

Schaeffer, John D. (1990). Sensus Communis. Vico, Rethoric and the Limits of Relativism. Duke: Duke University Press.

Shaftesbury, John D. (1995). Sensus communis: Ensayo sobre la libertad de ingenio y humor. Valencia: Pre-Textos.

Sánchez Barbero, Francisco (1834). Principios de Retórica y Poética. Madrid: Norberto Llorenci.

Sánchez García, Raquel (2008). «Del pueblo heroico al pueblo resistente. La Guerra de la Independencia en la literatura», en Joaquín Álvarez Barrientos, (ed.). La Guerra de la Independencia en la cultura española. Madrid: Siglo XXI, pp. 159-190.

Saura Sánchez, Alfonso (1992). «Significación y alcance del Discours sur l'ode de Houdar de La Motte», Anales de Filología Francesa. 4, pp. 111-129.

Stäel-Holstein, Madame (1800). De la littérature considerérée dans ses rapports avec las institutions sociales. Paris: Impr. Crapelet.

Stäel-Holstein, Madame (1991). Alemania, ed. de Guido Brunner. Madrid: Espasa-Calpe.

Urquijo, Mariano Luis (1791). Discurso del Traductor sobre el estado actual de nuestros teatro, y necesidad de su reforma. En La Muerte de César. Tragedia francesa de Mr. de Voltaire. Madrid: Blas Román.

Valella (1804). «El Filósofo. Carta», El Regañón General, 1804. N. . 33, 21 abr., p. 255.

Wolf, Richard B. (1988). «Shaftesbury's Wit in A Letter concerning Enthusiasm», Modern Philology, 86, 1, pp. 46-53.

Fecha de recepción: 3 de febrero de 2010

Fecha de aceptación: 14 de julio de 2010 